\title{
SYNTHESIS AND ANTICANCER ACTIVITY TEST OF 2-HYDROXY-N-PHENYLNICOTINAMIDE
}

\author{
Salahuddin ${ }^{1,2,}$, Muhammad Hanafi ${ }^{2,3}$, and Hariyanti ${ }^{1}$ \\ ${ }^{1}$ Faculty of Pharmacy, University of Uhamka, Perumnas Klender 13460, Jakarta, Indonesia \\ ${ }^{2}$ Research Centre for Chemistry - LIPI, Kawasan Puspiptek, Tangerang 15314, Indonesia \\ ${ }^{3}$ Faculty of Pharmacy, University of Pancasila, Lenteng Agung, Jakarta 12640, Indonesia
}

Received March 5, 2013; Accepted June 30, 2013

\begin{abstract}
The novel compound of 2-hydroxy-N-phenylnicotinamide was synthesized from modification of the UK-3A compound, which was known biologically active to inhibit bacterial and cancer cells growth. Synthesis of this compound was carried out in one-step reaction. Analog UK-3A compound namely 2-hydroxy-N-phenylnicotinamide was synthesized from 2-hydroxynicotinic acid as the starting material using amidation reaction with aniline in presence of DCC/DMAP in pyridine. Analog UK-3A was analyzed and identified using TLC, FT-IR, LC-MS and FTNMR spectrophotometer. The yield after purification was $42.97 \%$. The $I C_{50}$ value $85 \mu \mathrm{g} / \mathrm{mL}$ was obtained from cytotoxicity test against P388 Murine Leukemia cells. It indicated that the synthesis products were sufficiently potential for leukemia $P 388$ treatment.
\end{abstract}

Keywords: 2-hydroxy-N-phenyInicotinamide; UK-3A; amidation; P388 Murine Leukemia cells

\section{ABSTRAK}

Senyawa baru 2-hiroksinikotinil fenilamida telah disintesis dari modifikasi senyawa UK-3A, yang telah diketahui aktif secara biologi menghambat pertumbuhan bakteri dan sel kanker. Sintesis senyawa ini dilakukan dengan satu tahap reaksi. Senyawa analog UK-3A yaitu 2-hidroksinikotinil fenilamida disintesis dari asam 2-hidroksinikotinat sebagai bahan awal menggunakan reaksi amidasi dengan anilin terhadap DCC/DMAP dalam piridin. Analog UK-3A dianalisis dan diidentifikasi menggunakan KLT, FT-IR, LC-MS, FT-NMR spektrofotometer. Diperoleh rendemen setelah dipurifikasi sebesar $42,97 \%$. Nilai $I C_{50}$ diperoleh sebesar $85 \mu \mathrm{g} / \mathrm{mL}$ diperoleh dari uji sitotoksisitas terhadap sel leukemia murin P388. Ini mengindikasikan bahwa produk sintesis cukup berpotensi terhadap leukemia P388.

Kata Kunci: 2-hidroksinikotinil fenilamida; UK-3A; amidasi; sel leukemia murin P388

\section{INTRODUCTION}

Streptomyces sp. 517-02, from which a novel cytotoxic benzoxazole UK-1, antifungal nine membered dilactones UK-2A, B, C and D, antifungal antibiotic ninemembered UK-3A were previously isolated [1]. With a little yield obtained from isolation, UK-3A compound has anticancer potent to develop [2]. At present various research groups worldwide are involved in search of more safe anti-inflammatory and anticancer agents [3-6]. Cancer is the second leading cause of death [7] worldwide after cardiovascular diseases, according to WHO. Indeed, lung, breast, stomach, liver and colorectal cancers are the largest causes of death worldwide each year, and therefore the discovery and the development of suitable agents to treat various types of cancer are highly desirable [8].
Natural products have become a leading category of compounds in improving the rational drug design for novel anti-cancer therapeutics [9]. According to limited amount of yield resulted from natural product, it led to use synthesis methods. Total synthesis of UK-3A need many step of reaction as much as reagents and time. Perhaps, synthesis of UK-3A analog could get more simple compound with the same pharmacopore groups as UK-3A and also had the equal or more anticancer activities. Pharmacopore groups of UK-3A was determined by methylation reaction using diazomethane to get UK-3A (OMe) and UK-3A (Nme) with no anticancer activities and chain disconnection using dry $\mathrm{HCl}$ in methanol to get more un-active compounds (4-methoxy-3-hydroxypycolinyl methyl serine ester and 2-benzyl-3-hydroxy-4methyl-ýbutyrolactone).

* Corresponding author. Tel/Fax : +62-85772199113

Email address : uddin_net@yahoo.co.id 


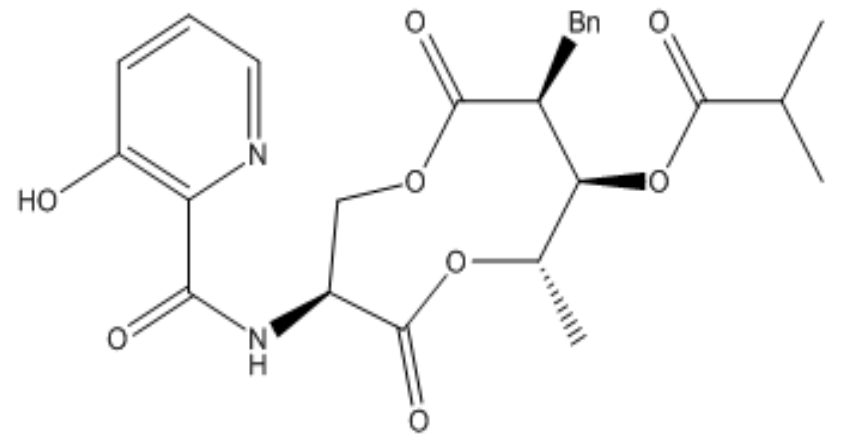

Fig 1. Structure of UK-3A

From the above process, UK-3A (Fig. 1) has three different pharmacopore groups, namely hydroxyl group on pyridine, amide group, and dilactone group. Retrosynthesis of UK-3A is used to obtain three commercial reagents (market ready) L-serine, 2-hydroxylnicotinic acid, and alcohol.

Anticancer active compound with simple molecule structure, easy step to synthesize, will give us more chances to treat and faces cancer diseases. With the same steps like synthesis of 2-hydroxy-Nphenylnicotinamide, there's a chance to synthesize another simple compound with the same or more biologically active than original compound [10]. Analog synthesis is advantageous due to its short duration and high probability of yielding a more active compound by modifying the structure, and it's also give information about the structure activity-relationship [11].

This research was focused on the nine membered dilactone ring itself, which was replaced by suitable mimetic structure, as shown in Fig. 1, and also we want to report the result of cytotoxic assay by changing nine membered dilactone ring with aniline.

\section{EXPERIMENTAL SECTION}

\section{Materials}

The compound was prepared from 2hydroxynicotinic acid (Sigma) as the main material. 1,3dicyclohexylcarbodiimide (DCC) and 4,4dimethylaminopyridine (DMAP) were used as the activator and catalyst. Dry pyridine (E. Merck) was used as solvent.

\section{Instrumentation}

Column chromatography was carried out using Merck silica gel $60 \mathrm{GF}_{254}$ and for TLC analysis precoated silica gel plates (Merck Kiesel-gel 60 GF254, 0.25mm) were used. Visualization of TLC plates was performed using ninhydrin spray reagents and UV lamp $254 \mathrm{~nm}$. Identification and purification of the compound were established by spectrophotometer LC-MS HP 5972 series, FT-IR Spectrophotometer Shimadzu 2010 A. ${ }^{1} \mathrm{H}$ and ${ }^{13} \mathrm{C}-\mathrm{NMR}$ spectra were recorded at $500 \mathrm{MHz}$ on JEOL (JNM-ECA).

\section{Procedure}

\section{Amidation}

The appropriate 2-hydroxynicotinic acid $(2 \mathrm{mmol})$ was dissolved in pyridine $(5 \mathrm{~mL})$ and aniline $(2.2 \mathrm{mmol})$ was added, followed by addition of DCC $(2.2 \mathrm{mmol})$ and DMAP $(0.2 \mathrm{mmol})$. The reaction mixture was heated to $55{ }^{\circ} \mathrm{C}$ and allowed to stir at this temperature for $24 \mathrm{~h}$. After stirring for $24 \mathrm{~h}$ at $55^{\circ} \mathrm{C}$, the mixture was acidified with $\mathrm{HCl} 2 \%$ and extracted with ethyl acetate. The combined organic layers were washed with $1 \%$ $\mathrm{NaOH}$ solution and brine, and dried over $\mathrm{MgSO}_{4}$. The filtrate was concentrated and purified by silica gel column chromatography (hexane 40\%-ethyl acetate $60 \%$ ) to give the condensation product [12].

\section{Cytotoxicity assay}

P388 cells seeded into 96-well plates at an initial cell density of approximately $3 \times 10^{4}$ cells $\mathrm{cm}^{-3}$. After 24 $\mathrm{h}$ of incubation of cell attachment and growth, varying concentrations of samples were added. The compound added was first dissolved in DMSO at the required concentration. Subsequent six desirable concentrations of samples were prepared using PBS (phosphoric buffer solution, $\mathrm{pH}$ 7.30-7.65). Control wells received only DMSO. The assay was terminated after $48 \mathrm{~h}$ incubation period by adding MTT reagent [3-(4,5dimethyl-thiazol-2-yl)-2,5-diphenyl tetrazolium bromide; also named as thiazol blue] and the incubation was continued for another $4 \mathrm{~h}$, in which the MTT-stop solution containing SDS (sodium dodecyl sulphate) was added and another $24 \mathrm{~h}$ of incubation was conducted. Optical density was read by using a micproplate reader at $550 \mathrm{~nm}$. $\mathrm{IC}_{50}$ values were taken from the plotted graph of percentage live cells compared to control (\%), receiving only PBS and DMSO, versus the tested contraction of compounds $(\mu \mathrm{M})$. The $\mathrm{IC}_{50}$ value was the concentration required for $50 \%$ growth inhibition. Each assay and analysis was run in triplicate and averaged [13-15].

\section{RESULT AND DISCUSSION}

2-Hydroxy-N-phenylnicotinamide was obtained as a white smooth crystal from amidation reaction between 2-hydroxynicotinic acid and aniline, in the presence of DCC/DMAP and in pyridine as shown as Fig. 2. The purification and identification were conducted by $\mathrm{SiO}_{2}$ column chromatography that showed positive reaction with ninhydrin reagent and 
<smiles>O=C(O)c1cccnc1O</smiles>

2-hydroxynicotinic acid aniline

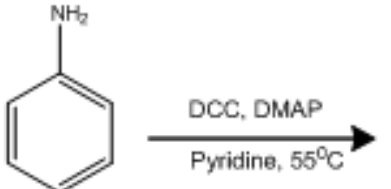<smiles>O=C(Nc1ccccc1)c1cccnc1O</smiles>

2-hydroxy-N-phenylnicotinamide

Fig 2. Synthesis of UK-3A Analog (2-hydroxy-N-phenylnicotinamide)

Table 1. Results of cytotoxicity test against P388 Murine Leukemia cells

\begin{tabular}{|c|c|c|c|c|c|}
\hline No & Products & Structure & $\begin{array}{c}\mathrm{IC}_{50} \\
(\mu \mathrm{g} / \mathrm{mL})\end{array}$ & Reported by & Years \\
\hline 1 & $\begin{array}{l}\text { 2-hydroxy-N- } \\
\text { phenylnicotinamide }\end{array}$ & & 85 & Salahuddin & 2012 \\
\hline 2 & UK-3A & & 38 & M. Hanafi & 1997 \\
\hline 3 & $\begin{array}{l}\text { 2-hydroxy- } N \text { - } \\
\text { octylbenzalamide }\end{array}$ & & 7.5 & M. Hanafi & 2008 \\
\hline 4 & $\begin{array}{l}\text { 2-hydroxy-N- } \\
\text { Phenylbenzalamide }\end{array}$ & & 7.75 & M. Hanafi & 2008 \\
\hline 5 & $\begin{array}{l}\text { (S)-2-(3- } \\
\text { hydroxypicolinamido)-3- } \\
\text { methoxy-3-oxopropyl } \\
\text { hexanoate }\end{array}$ & & 40 & Y. Anita & 2007 \\
\hline 6 & $\begin{array}{l}\text { (S)-2-(3- } \\
\text { hydroxypicolinamido)-3- } \\
\text { methoxy-3-oxopropyl } \\
\text { nonanoate }\end{array}$ & & 15.4 & Y. Anita & 2007 \\
\hline 7 & $\begin{array}{l}\text { 2-hdroxy-N- } \\
\text { octylnicotinamide }\end{array}$ & & 32 & Hariyanti & 2010 \\
\hline
\end{tabular}

obtained product in $42.97 \%$. The product was established by LC-MS shown molecular ion at: $\mathrm{m} / \mathrm{z}$ $215.23 \mathrm{~m} / \mathrm{z}[\mathrm{M}+\mathrm{H}]^{+}$, which was the molecular weight of amidation product $(\mathrm{M}=214.23)$. The presence of amide $(\mathrm{CONH})$ was identified by the FT-IR absorption at $3309.85 \mathrm{~cm}^{-1}$.
The product was confirmed as well by ${ }^{1} \mathrm{H}$ and ${ }^{13} \mathrm{C}$ NMR spectra (500 MHz, $\mathrm{CDCl}_{3}$ ), as shown in Fig. 2. A signal ${ }^{1} \mathrm{H}$ for the phenolic $\mathrm{OH}$ proton was seen at $\delta_{\mathrm{H}}$ 11.69 (s). This downfield-shifted signal suggested the formation of an intramolecular hydrogen bond between the phenolic $\mathrm{OH}$ proton and the carbonyl oxygen of amide bond. The presence of phenyl aromatic chain was 
Table 2. Chemical shift data for 2-hydroxy-N-phenylnicotinamide

\begin{tabular}{clc}
\hline \multirow{2}{*}{ No. } & \multicolumn{2}{c}{ Chemical shift $(\delta, J$ in $\mathrm{Hz})$} \\
\cline { 2 - 3 } & \multicolumn{1}{c}{${ }^{1} \mathrm{H}-\mathrm{NMR}$} & 169.44 \\
\hline 2 & - & 125.64 \\
3 & - & 133.71 \\
4 & $8.74(\mathrm{dd}, 1 \mathrm{H}, j=2.6 ; 7.1)$ & 108.73 \\
5 & $6.61(t, 1 \mathrm{H}, J=7.1)$ & 140.69 \\
6 & $7.58(\mathrm{~d}, 1 \mathrm{H}, j=5.15)$ & 164.52 \\
$(-\mathrm{CONH})$ & $11.13(\mathrm{~s}, 1 \mathrm{H})$ & 139.51 \\
$1^{\prime}$ & - & 121.60 \\
$2^{\prime}, 6^{\prime}$ & $7.75(\mathrm{~d}, 2 \mathrm{H}, J=7.8)$ & 130.15 \\
$3^{\prime}, 5^{\prime}$ & $7.37(t, 2 \mathrm{H}, j=7.8)$ & 129.97 \\
$4^{\prime}$ & $7.16(t, 1 \mathrm{H}, J=7.8)$ & - \\
$2-\mathrm{OH}$ & $11.69(\mathrm{~s}, 1 \mathrm{H})$ & \\
\hline
\end{tabular}
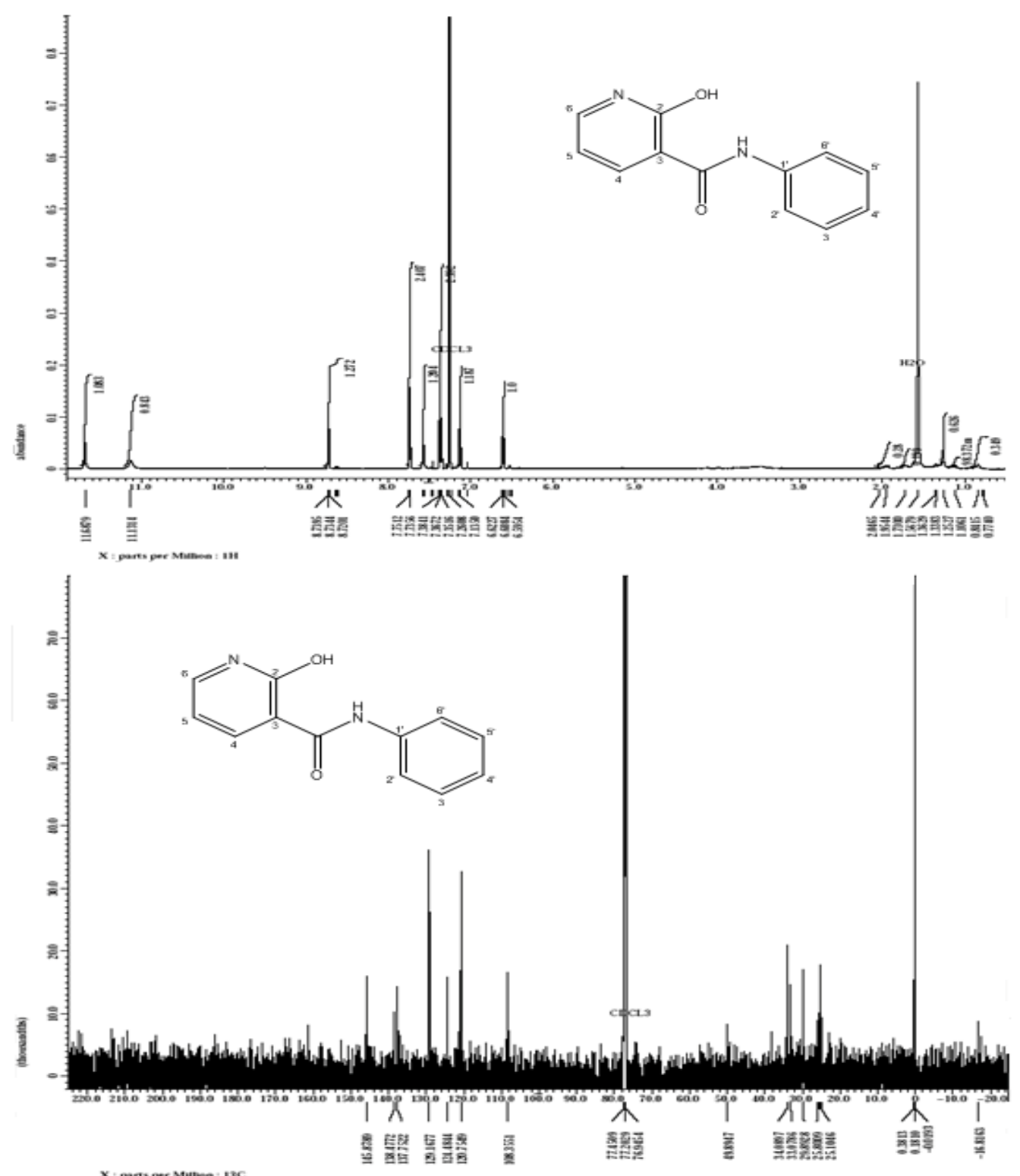

Fig 3. ${ }^{1} \mathrm{H}$ and ${ }^{13} \mathrm{C}-\mathrm{NMR}$ spectra $\left(500 \mathrm{MHz}, \mathrm{CDCl}_{3}\right)$ of amidation product 
determined by the signal proton at $\delta_{H} 7.16-7.75$, as shown in Table 2. The signals of phenyl aromatic chain was also determined by $\delta_{C} 121.60-139.51$, and the signals ${ }^{1} \mathrm{H}$ and ${ }^{13} \mathrm{C}$ for $\mathrm{CONH}$ were seen at $\delta_{\mathrm{H}}$ and $\delta_{\mathrm{C}}$ at $8.74 ; 164.5$, respectively.

UK-3A compound had been isolated from the mycelium of Streptomyces sp. 517-02 [1]. The compound was then acknowledged to have a high activity against mouse leukemia cells, P388 $\left(\mathrm{IC}_{50}=38\right.$ $\mu \mathrm{g} / \mathrm{mL}$ ) [2]. The cytotoxicity of 2-hydroxy-Nphenylnicotinamide was evaluated against murine leukemia P388 cells. This compound has anticancer against P388 leukemia cells with $\mathrm{IC}_{50} 85 \mu \mathrm{g} / \mathrm{mL}$ lower than UK-3A $\left(I_{50}=38 \mu \mathrm{g} / \mathrm{mL}\right)$, as shown in Table 1. The $I_{50}$ values indicated that the synthesis products were sufficiently potential for leukemia P388 treatment.

Analog is compound having a structure similar to that of another one, but different from it in respect of a certain component. It can differ in one or more atoms, functional groups, or substructures, which are replaced with other atoms, groups, or substructures. A structural analog can be imagined to be formed, at least theoretically, from the other compound. Analog UK-3A (2-hydroxy-N-phenylnicotinamide) has pharmacopore groups, namely amide group and hydroxyl group on pyridine. UK-3A has three different pharmacopore groups, namely hydroxyl group on pyridine, amide group, and dilactone group. Structure modification of UK-3A analog here was done by changing dilactone close chain with variation of hydrocarbon chains. That is the reason why 2-hydroxy-N-phenylnicotinamide should be called as a UK-3A analog.

\section{CONCLUSION}

Synthesis of UK-3A analog as an anticancer active compound has been done by one simple step of reaction (amidation). In vitro test to leukemia P388 cells demonstrated that the inhibition to growth of cancer cells with the $\mathrm{IC}_{50}$ for 2-hydroxy-N-phenylnicotinamide was 85 $\mu \mathrm{g} / \mathrm{mL}$, respectively. The $I_{50}$ values indicated that the synthesis products were sufficiently potential for leukemia P388 treatment.

\section{ACKNOWLEDGEMENT}

This research was supported by Indonesian Institute of Sciences (LIPI) and the Directorate General of Higher Education (DGHE or DIKTI), which were gratefully appreciated.

\section{REFERENCES}

1. Ueki, M., Kusumoto, A., Hanafi, M., Shibata, K., Tanaka, T., and Taniguchi, M., 1997, J. Antibiot., $50,551-555$.

2. Hanafi, M., 1995, Studies of Novel Antibiotic Metabolites from Streptomyces Sp. 517-02, Department of Chemistry, Faculty of Science, Osaka City University

3. Moutevelis-Minakakis, P., Papavassilopoulou, E., Michas, G., Georgikopoulou, K., Ragoussi, M-E., Neophytou, N., Zoumpoulakis, P., Mavromoustakos, T., and Hadjipavlou-Litina, D., 2011, Bioorg. Med. Chem., 19, 9, 2888-2902

4. Marrero-Ponce, Y., Siverio-Mota, D., GálvezLlompart, M., Recio, M.C., Giner, R.M., GarcíaDomènech, R., Torrens, F., Arán, V.J., CorderoMaldonado, M.L., Esguera, C.V., de Witte, P.A., and Crawford, A.D., 2011, Eur. J. Med. Chem., 46, 12, 5736-5753.

5. Tripodi, F., Pagliarin, R., Fumagalli, G., Bigi, A., Fusi, P., Orsini, F., Frattini, M., and Coccetti, P., 2012, J. Med. Chem., 55, 5, 2112-2124.

6. Li, W-S.,Wang, C-H., Ko, S., Chang, T.T., Jen, Y.C., Yao, C-F., More, S.V., and Jao, S-C., 2012, J. Med. Chem., 55, 4, 1583-1592

7. Parkin, D.M., Bray, F., Ferlay, J., and Pisani, P., 2005, CA Cancer J. Clin., 55, 2, 74-108

8. Rajitha, C., Dubey, P.K., Sunku, V., Piedrafita, F.J., Veeramaneni, V.R., and Pal, M., 2011, Eur. J. Med. Chem., 46, 10, 4887-4896.

9. Zhang, Y., Lv, Z., Zhong, H., Geng, D., Zhang, M., Zhang, T., Li, Y., Li, K., 2012, Eur. J. Med. Chem., 53, 356-363.

10. Darmawan, A., Hanafi, M., and Anita, Y., 2008, Proceeding of the International Seminar on Chemistry, Jatinangor, 735-738.

11. Arsianti, A., Hanafi, M., Saepudin, E., Morimoto, T., and Kakiuchi, K., 2010, Bioorg. Med. Chem. Lett., 20, 14, 4018-4020.

12. Anita, Y., Hanafi, M., Putra, A.M.J., Arifin, S., Usuki, Y., and Lio, H., 2007, Indo. J. Chem., 7, 2, 214-217

13. Usuki, Y., Adachi, N., Fujita, K-I., Ichimura, A., Lio, H., and Taniguchi, M., 2006, Bioorg. Med. Chem. Lett., 16, 12, 3319-3322.

14. Sahidin, and Hakim, EH. 2006, Cytotoxic Properties of Oligostillbenoids from the Tree Barks of Hopea Dryobalamides. 60c, 723.

15. Shimano, M., Kamei, N., Shibata, T., Inoguchi, K., Itoh, N., Ikari, T., and Senda, H. 1998. Tetrahedron, 54, 42, 12745-12774

16. Arya, S., Kumar, N., Roy, P., and Sondhi, S.M., 2013, Eur. J. Med. Chem., 59, 7-14. 